ISSN: 2581-8341

Volume 04 Issue 02 February 2021

DOI: 10.47191/ijesrr/V4-i2-07, Impact Factor: 6.825

IJCSRR@ 2021

www.ijcsrr.org

\title{
Dynamics of Erythrocyte Sedimentation Rate vs. C - reactive protein: Peas in a Pod or Chalk and Cheese?
}

\author{
Arash Eatemadi ${ }^{1}$, Ali Al Madhani ${ }^{2}$, Ahmed Al Maqbali ${ }^{3}$, Hamid Moradzadegan ${ }^{4}$ \\ ${ }^{1}$ Division of Infectious Diseases, General Medicine Department, Suhar hospital, Suhar, Sultanate of Oman \\ ${ }^{2}$ Division of Hematology, General Medicine Department, Suhar hospital, Suhar, Sultanate of Oman \\ ${ }^{3}$ Division of Rheumatology, General Medicine Department, Suhar hospital, Suhar, Sultanate of Oman \\ ${ }^{4}$ Laboratory and Blood bank Department, Arvand hospital, Ahwaz, Iran
}

\begin{abstract}
Acute phase reactants have a supplementary role in the management of hospitalized patients with fever. While not perfect tools, they have some role in formulating a diagnostic and therapeutic plan and may improve antimicrobial stewardship. The Erythrocyte sedimentation rate (ESR) and C-reactive protein (CRP), while not specific enough to establish a diagnosis, can be helpful in guiding the intensity and duration of anti-infective therapy. However, they have different dynamics during inflammations and infections.
\end{abstract}

KEY WORDS: Acute phase reactants, Erythrocyte Sedimentation Rate (ESR), C-Reactive Protein (CRP)

\section{INTRODUCTION}

Clinical decision making often depends on laboratory data, especially if the patient suspected to infection or other inflammatory disorders. Lab findings may influence decisions about antibiotic therapy in critically ill patients.

Inflammatory processes are followed by release of a sub-class of proteins known as acute phase reactants (APRs). They are a heterogeneous group of plasma proteins that either increase, means positive acute phase reactants (CRP, serum amyloid A, Ceruloplasmin and complement proteins, fibrinogen) or decrease, means negative acute phase reactants (Albumin, transferrin, transthyretin, retinol binding proteins) (1) in response to inflammatory stimuli such as infections, trauma, autoimmune disorders, and malignancy. (2)

The emerging response is usually correlated to the intensity of the inflammatory stimulus which is mediated by proinflammatory cytokines such as interleukin (IL)-6, IL-1, tumor necrosis factor-alpha, and interferon gamma. These cytokines, which are produced by macrophages, monocytes, and other cells participating in the inflammatory response, then triggered production of APRs. Most APRs are mainly produced by the liver, although other cell types such as macrophages, endothelial cells, fibroblasts, and adipocytes have been implicated in the synthesis. (1) ESR is an indirect measure of APR proteins mostly fibrinogen, so, is an "indirect" APR. (3) Despite their name, acute phase reactants increase in both acute and chronic inflammation and that is why the interpreting APRs results could be difficult in some situations.

\section{ERYTHROCYTE SEDIMENTATION RATE}

One of the oldest of tests for APRs, is the erythrocyte sedimentation rate (ESR). ESR was first reported by Dr. Edmund Faustyn Biernacki in 1897. (4) He reported this index reflects the distance in millimeters red blood cells descend in a tube over 1 hour. He observed that the rate at which blood settled varied among different individuals, that blood with smaller amounts of erythrocytes settled faster, and the rate of settling depended on plasma fibrinogen levels. He also noted that ESR was high in patients with febrile diseases associated with high fibrinogen levels (eg, rheumatic fever), whereas it was low in defibrinated blood. ESR value can be estimated nearly by dividing the age in years by 2 in men; add 10 to age in years for women and divide by 2 . Normal ESR value for men is $0-15 \mathrm{~mm} / \mathrm{h}$, and for women $0-20 \mathrm{~mm} / \mathrm{h}$.

ESR is a non-specific test that indirectly measure acute phase reaction as a positive inflammatory marker. The ESR rises within 2448 hours of the onset of inflammation and falls back slowly with resolution of inflammation. (5) The inflammation associated with infection, malignancy, ischemia, and collagen vascular diseases tends to increase fibrinogen levels and, thereby, increase the ESR, however, it can be normal in critically ill patients. (6) 


\section{International Journal of Current Science Research and Review}

ISSN: 2581-8341

Volume 04 Issue 02 February 2021

DOI: 10.47191/ijcsrr/V4-i2-07, Impact Factor: 6.825

IJCSRR@ 2021

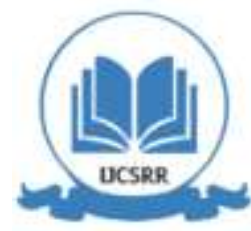

www.ijcsrr.org

The ESR is influenced by increasing concentrations of some proteins such as immunoglobulins (especially IgG) and fibrinogen. Erythrocytes are negatively charged and in the presence of these positively charged proteins increase the rate at which red blood cells settle in the plasma. $(7,8)$ Because fibrinogen and immunoglobulins are two of the major proteins affecting ESR, and because both have relatively long half-lives (100 hours and more than one week, respectively), ESR remains elevated for days to weeks after resolution of inflammation. $(9,10)$ ESR also may be confounded by other factors unrelated to inflammation. (Table 1)

Marked ESR increases (>100 mm/hr) are associated most often with infection (33\%) and malignancy (17\%), however end stage renal disease (ESRD) is also a significant cause. (11) In a large retrospective study of 1006 patients, an ESR of $100 \mathrm{~mm} / \mathrm{hour}$ or more had low sensitivity of 0.36 among patients with infection, 0.25 among those with malignant neoplasms, and 0.21 among patients with noninfectious inflammatory disorders. However, specificity was high: 0.96 for malignant neoplasms, 0.97 for infections, and 0.99 as a "sickness" index. The positive predictive value (PPV) for an identifiable cause of marked ESR elevation was $90 \%$. (12)

Table 1: Confounding factors influence ESR

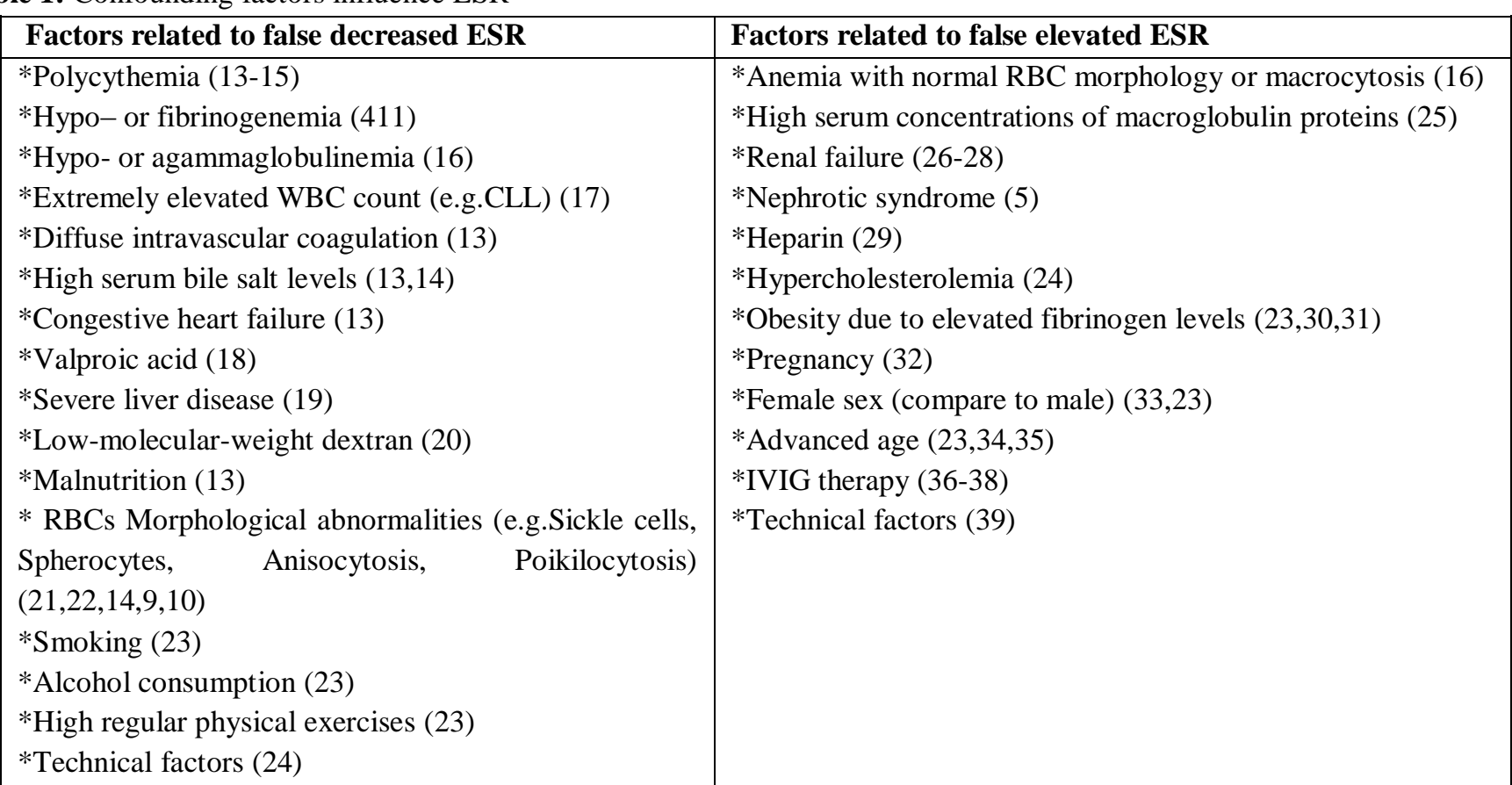

\section{C-REACTIVE PROTEIN}

CRP was first discovered in 1930 by Tillet and Francis during their serologic studies of patients with pneumococcal pneumonia. (40) They observed precipitation in the serum of sick patients, noting that precipitation decreased as patients recovered. They concluded that precipitation occurred due to a protein in the serum that reacted with the C-polysaccharide of pneumococcal cell walls, so, they named it "C-reactive protein." $(41,42)$

$\mathrm{C}$-reactive protein is a component of the innate immune response and positive direct inflammatory marker. In the presence of inflammation, cytokines, particularly interleukin (IL)-1 beta, IL-6, and tumor necrosis factor (TNF) trigger hepatocytes to produce CRP. CRP binds to pathogens as an opsonin and activates complement by the classical C1q pathway. (43)

The main determinant of CRP level is the synthesis rate, which increases according to the intensity of the inflammatory process. (44) CRP begins to rise within 4-6 hours after the onset of inflammation and peaks within 36-50 hours. CRP level drops fast after inflammation resolves. (45). Also, considering its short half-life, it could be used for both diagnosis and response to treatment. (46) Of note, CRP is not specific test and there are some confounders that influence its level. (47) (Tab 2)

In healthy individuals, the CRP level is generally below $2 \mathrm{mg} / \mathrm{L}$ but can be up to $10 \mathrm{mg} / \mathrm{L}$. A proposed calculation for CRP is the upper limit of the reference range $(\mathrm{mg} / \mathrm{dL})$ equals (age in years)/50 for men and (age in years/50) +0.6 for women. (48) 


\section{International Journal of Current Science Research and Review}

ISSN: 2581-8341

Volume 04 Issue 02 February 2021

DOI: 10.47191/ijcsrr/V4-i2-07, Impact Factor: 6.825

IJCSRR@ 2021

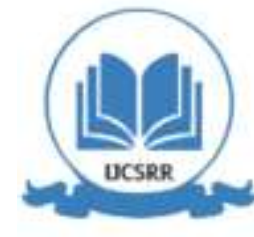

www.ijcsrr.org

In non-severe infections such as uncomplicated skin infection and cystitis, CRP can rise to 50-100 mg/L within 6 hours. (44) little elevated CRP, with values between $2 \mathrm{mg} / \mathrm{L}$ and $10 \mathrm{mg} / \mathrm{L}$, may be seen with "metabolic inflammatory" states such as smoking, uremia, cardiac ischemia, and other low level noninfectious inflammatory conditions. However, extremely high CRP elevation of more than $500 \mathrm{mg} / \mathrm{L}$, in 1 study, was associated with more than $80 \%$ likelihood of bacterial infections. $(49,50)$

Clinicians should be aware about variations in the units by which CRP levels are reported with some laboratories measuring CRP concentrations in $\mathrm{mg} / \mathrm{dL}$, others using $\mathrm{mg} / \mathrm{L}$.

Table 2: Confounding factors influence CRP

\begin{tabular}{|l|l|}
\hline Factors related to false decreased CRP & Factors related to false elevated CRP \\
\hline Overwhelming sepsis (52) & Obesity (40) \\
liver failure (51-53) & Smoking (54) \\
& Diabetes (55) \\
& hypertension (56) \\
& fatigue (57) \\
& depression (58) \\
& advanced age (59) \\
\hline
\end{tabular}

\section{DIFFERENCES BETWEEN ESR AND CRP}

CRP and the ESR are popular and inexpensive tests that use to measure acute phase reactions. They are usually ordered together. Both of them are known to lack specificity and sensitivity, and neither should be used per se for diagnosing any infectious or inflammatory disorder. However, if used in appropriate settings besides perfect clinical history and physical exam, they have important role in clinical practice.

C-reactive protein has some advantages over ESR because it seems to be a better measure of an acute-phase response and is also more sensitive than ESR to subtle changes in the acute-phase response. (2) Conversely, measurement of ESR is beneficial in the monitoring of chronic inflammatory conditions such as systemic lupus erythematosus (SLE) or inflammatory bowel diseases (IBD). As discussed above, many factors can falsely increase or decrease ESR, whereas CRP is less likely to be affected (Table 2) There are only two circumstances where the ESR is superior to CRP-detecting low-grade bone and joint infections, and monitoring disease activity in SLE. (60) CRP changes minimally with age, whereas ESR rises with age and is generally higher in females. (45) Osei-Bimpong et al. measured CRP and ESR in 295 healthy subjects. The results showed a mean ESR of $10 \mathrm{~mm} / 1 \mathrm{~h}$ (range 0-25) in both males and females below the age of 40 years; this increased with age, to a mean of $18 \mathrm{~mm}$ (range 0-35) by 60 years in both men and women. In the CRP test, $95 \%$ of the samples in the $>40$ years group had CRP range of $0-18 \mathrm{mg} / \mathrm{l} \mathrm{compared} \mathrm{with} 0-10 \mathrm{mg} / \mathrm{l}$ in the younger subjects. The distribution plot of CRP results showed a left skew with mode at about $2 \mathrm{mg} / \mathrm{l}$, whereas the equivalent ESR distribution shows a broad plateau with less skew. there was more overlapping of the numerical values for ESR and CRP in subjects younger than 40 years, as compared with those over 40 years old in whom the two sets of measurements were well separated. (61)

CRP levels drop faster than ESR, normalizing 3 to 7 days after resolution of tissue injury, whereas ESR can take up to weeks to normalize. Thus, it is appropriate to use CRP for monitoring "acute" disease activity such as acute infection (e.g, pneumonia, orbital cellulitis). (62) However, this resulting in transient test disagreements, either on initial testing or during the course of the illness or recovery from it. This timing issue in relation to test result interpretation is clinically important and should be taken into account in follow-up visits. Sbong et al. analyzed simultaneously ordered CRP and ESR results in 70 adult patients who had been tested on three separate occasions a median of 4 weeks apart. Initial CRP/ESR disagreements occurred in 14 of the 70 patients $(20 \%$; $95 \%$ CI, 12-31). Only four of these 14 patients had stable CRP/ESR disagreements throughout the study. The other 10 patients with initial CRP/ESR disagreements later exhibited CRP/ESR agreements. Of the 56 patients with initial CRP/ESR agreements, only 10 developed a CRP/ESR disagreement (or disagreements) on subsequent testing. (63) In another large French cohort of hospitalized patients, the two tests disagreed (one high and one normal) in $33 \%$ of cases. (64) 


\section{International Journal of Current Science Research and Review}

ISSN: 2581-8341

Volume 04 Issue 02 February 2021

DOI: 10.47191/ijcsrr/V4-i2-07, Impact Factor: 6.825

IJCSRR@ 2021

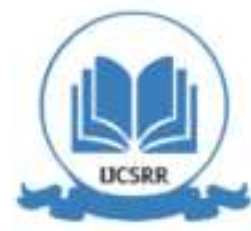

www.ijcsrr.org

Generally, acute bacterial infections tend to elevate CRP to levels of 150 to $350 \mathrm{mg} / \mathrm{L}$, whereas acute viral infections are usually associated with lower levels. However, sometimes viral infections caused by adenovirus, influenza, and cytomegalovirus could be associated with CRP levels of up to $100 \mathrm{mg} / \mathrm{L}$. (45)

Patients with high CRP but normal ESR typically have infection, ischemia, or thromboembolism. (65) On the other hand, patients with high ESR but normal CRP may have systemic inflammatory or autoimmune processes, including those associated with malignancy. For example, patients with active SLE may have normal CRP even with an elevated ESR; this could be related to high levels of type 1 interferon that can inhibit hepatic production of CRP. (66)

Buess et al. in a prospective study evaluated the diagnostic relevance of CRP as a screening parameter for inflammatory diseases was compared to the ESR. After taking history and clinical examination, the responsible physician had to answer a first questionnaire and a second at the time of patient discharge. At the time of admission, elevation of CRP was expected by the treating physician in $40.3 \%$ of patients, and elevation of ESR in $43.2 \%$. An unexpected elevation of CRP or ESR was found in 38/303 cases (12.5\%). In 22/38 patients only CRP was elevated, but ESR only was elevated in 13/38 cases. In summary, measurement of CRP and/or ESR was felt by the treating physician to have been helpful in $25.1 \%$ of all patients. Due to the fast rise of CRP, all patients with bacterial pneumonia showed increased CRP at the time of hospitalization (23/23), but the ESR was still in normal range in some of these patients (normal ESR in 5/23). (67)

Finally, CRP is unique because it can be used in cardiovascular risk assessment for patients. It has been shown in patients with acute coronary syndromes that increased CRP levels measured by the high sensitivity (hsCRP) assay are indicative of poor cardiovascular prognosis. (68)

In Conclusion, ESR and CRP both play an important role in clinical practice. In certain disease states, one may be a more favorable tool to use over the other. It is important to take note of the situations during which it is advised to obtain both, and those during which it would be redundant to do so. CRP It is not a screening test for wellness and should only be used in the diagnosis and monitoring of a patient who appears to have an inflammatory process. Compared to the ESR, CRP is a more sensitive and specific marker of the acute phase reaction and is more responsive to changes in the patient's condition.

\section{REFERENCES}

1. Gabay C, Kushner I. Acute-phase proteins and other systemic responses to inflammation. N Engl J Med 1999; 340:44854.

2. Dowton SB, Colten HR. Acute phase reactants in inflammation and infection. Semin Hematol 1988; 25:84-90.

3. Bedell SE, Bush BT. Erythrocyte sedimentation rate. From folklore to facts. Am J Med 1985; 78:1001-9.

4. Grzybowski A, Sak JJ. Who discovered the erythrocyte sedimentation rate? J Rheumatol. 2011;38(7):1521-1522; author reply 1523. doi:10.3899/jrheum.101312

5. Shusterman N, Kimmel PL, Kiechle FL et al. Factors influencing erythrocyte sedimentation in patients with chronic renal failure. Arch Intern Med 1985; 145:1796-9.

6. Bitik B, Mercan R, Tufan A, et al. Differential diagnosis of elevated erythrocyte sedimentation rate and C-reactive protein levels: a rheumatology perspective. Eur J Rheumatol 2015; 4:131-4.

7. Husain TM, Kim DH, C-reactive protein and erythrocyte sedimentation rate in orthopaedics. Univ Pennsylvania Orthop J. 2002; 15:13-16.

8. Wilson DA. Immunologic tests. In: Walker HK, Hall WD, Hurst JW, eds. Clinical Methods: The History, Physical, and Laboratory Examinations. 3rd ed. Boston, MA: Butterworth-Heineman; 1990.

9. Batlivala SP. Focus on diagnosis: the erythrocyte sedimentation rate and the C-reactive protein test. Pediatr Rev. 2009;30(2):72-74. doi:10.1542/pir.30-2-72

10. C Gabay, I Kushner. "Acute-Phase Proteins and Other Systemic Responses to Inflammation." New England Journal of Medicine 340.17 (1999): 1376. Web.

11. Fincher, R. M. "Clinical Significance of Extreme Elevation of the Erythrocyte Sedimentation Rate." Archives of Internal Medicine 146.8 (1986): 1581-583. Web.

12. Fincher RM, Page MI. Clinical significance of extreme elevation of the erythrocyte sedimentation rate. Arch Intern Med 1986; 146:1581-3. 


\section{International Journal of Current Science Research and Review}

ISSN: 2581-8341

Volume 04 Issue 02 February 2021

DOI: 10.47191/ijcsrr/V4-i2-07, Impact Factor: 6.825

IJCSRR@ 2021

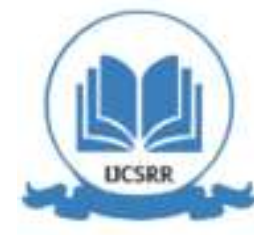

www.ijcsrr.org

13. Rafael L. Jurado. Why Shouldn't We Determine the Erythrocyte Sedimentation Rate? Clin Inf Dis, Volume 33, Issue 4, 15 August 2001, Pages 548-549, https://doi.org/10.1086/322605

14. Jurado, Rafael L. "Why Shouldn't We Determine the Erythrocyte Sedimentation Rate?" Clinical Infectious Diseases 33.4 (2001): 548-49. Web.

15. Brigden ML. Clinical utility of the erythrocyte sedimentation rate. Am Fam Physician. 1999;60(5):1443-1450.

16. Melissa Kaori Silva Litao, Deepak Kamat. Erythrocyte Sedimentation Rate and C-Reactive Protein: How Best to Use Them in Clinical Practice. Pediatric Annals. 2014;43(10):417-420https://doi.org/10.3928/00904481-20140924-10

17. Glass R. Factitiously low ESR in chronic lymphocytic leukemia, N Engl J Med, 1971, vol. 285 pg. 921

18. Hutchinson RM, Clay CM, Shapiro MR, Wood JK. Lowered ESR with sodium valproate, Lancet, 1978, vol. 2 pg. 1309

19. Silvestre JP, Coelho LM, Povoa PM. Impact of fulminant hepatic failure in C-reactive protein?J Crit Care. 2010;25(4): 657.e7-12. doi: 10.1016/j.jcrc.2010.02.004

20. Shanbrom E, Berger RH. Observations on the inhibition of erythrocyte sedimentation rate by low molecular weight dextran, Am J Med Sci, 1963, vol. 246 pg. 289

21. Jandl JH. Jandl JH. Physiology of red blood cells, Textbook of hematology, 19962d ed.New YorkLittle, Brown(pg. 1534)

22. Bunting H. Sedimentation rates of sickled and nonsickled cells from patients with sickle cell anemia, Am J Med Sci, 1939, vol. 198 (pg. 191-3)

23. Alende-Castro, Vanessa MDa; Alonso-Sampedro, Manuela PhDa,b; Vazquez-Temprano, Nuria MDa; Tuñez, Carmen MDc; Rey, Daniel MDc; García-Iglesias, Carmen MDc; Sopeña, Bernardo MD, PhD a; Gude, Francisco MD, PhDb; Gonzalez-Quintela, Arturo MD, PhD a,* Factors influencing erythrocyte sedimentation rate in adults, Medicine: August 2019 - Volume 98 - Issue 34 - p e16816 doi: 10.1097/MD.0000000000016816

24. Morris MW, Davey FR. Henry JB. Basic examination of blood, Clinical diagnosis and management by laboratory methods, 199619th ed. Baltimore WB Saunders

25. Rafael L. Jurado, Why Shouldn't We Determine the Erythrocyte Sedimentation Rate? Clin Inf Dis, Volume 33, Issue 4, 15 August 2001, Pages 548-549, https://doi.org/10.1086/322605

26. Shusterman N, Kimmel PL, Kiechle FL, et al. Factors influencing erythrocyte sedimentation in patients with chronic renal failure, Arch Intern Med, 1985, vol. 145 (pg. 1796-17)

27. Shusterman N, Morrison G, Singer I, Kimmel P, Kielchle F. The erythrocyte sedimentation rate and chronic renal failure, Ann Intern Med, 1985, vol. 105 pg. 801

28. Warner DM, George CRP. Erythrocyte sedimentation rate and related factors in end stage renal failure, Nephron, 1991, vol. 57 pg. 248

29. Penchas S, Stern Z, Bar-Or D. Heparin and the ESR, Arch Intern Med, 1978, vol. 138 (pg. 1864-5)

30. Pasulka PS, Bistrian BR, Blackburn GL. Obesity and erythrocyte sedimentation rate, Ann Intern Med, 1985, vol. 103 pg. 304

31. Grace CS, Goldrick RB. Fibrinolysis and body build, J Atheroscler Res, 1968, vol. 8 (pg. 705-19)

32. Fahreaus H. The suspension stability of the blood, Acta Med Scand, 1958, vol. 161 pg. 151

33. Shearn MA, Kang IJ. Effect of sex and age on erythrocyte sedimentation rate, J Rheumatol, 1986, vol. 13 pg. 297

34. Bottiger LE, Svedberg CA. Normal erythrocyte sedimentation rate and age, Br Med J, 1967, vol. 2 pg. 85

35. Zauber NP, Zauber AG. Hematologic data of healthy very old people, JAMA, 1987, vol. 257 pg. 1281

36. Newburger JW, Takahashi M, Gerber MA, et al. Committee on Rheumatic Fever, Endocarditis, and Kawasaki Disease, Council on Cardiovascular Disease in the Young, American Heart Association. Diagnosis, treatment, and long-term management of Kawasaki disease: a statement for health professionals from the Committee on Rheumatic Fever, Endocarditis, and Kawasaki Disease, Council on Cardiovascular Disease in the Young, American Heart Association. Pediatrics. 2004;114(6):1708-1733. doi:10.1542/peds.2004-2182

37. Nimmerjahn F, Ravetch JV. The antiinflammatory activity of IgG: the intravenous IgG paradox. J Exp Med. 2007; 204(1): 11-15. doi:10.1084/jem.20061788 
ISSN: 2581-8341

Volume 04 Issue 02 February 2021

DOI: 10.47191/ijesrr/V4-i2-07, Impact Factor: 6.825

IJCSRR@ 2021

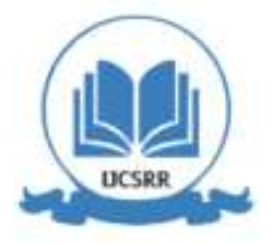

www.ijcsrr.org

38. Salehzadeh F, Noshin A, Jahangiri S. IVIg effects on erythrocyte sedimentation rate in children. Int J Pediatr. 2014; 2014:981465. doi:10.1155/2014/981465

39. Wintrobe MM, Landsberg JW. A standardized technique for the blood sedimentation, Am J Med Sci, 1935, vol. 189 (pg. 101-115)

40. Visser M, Bouter LM, McQuillan GM, et al. Elevated C-reactive protein levels in overweight and obese adults. JAMA 1999;282(22):2131-2135.

41. Tillett WS, Francis T. Serological reactions in pneumonia with a non-protein somatic fraction of pneumococcus. J Exp Med 1930; 52:561-71.

42. Vermeire S, Van Assche G, Rutgeerts P. C-reactive protein as a marker for inflammatory bowel disease. Inflamm Bowel Dis. 2004;10 (5):661-665. doi:10.1097/00054725-200409000-00026

43. Bray C, Bell LN, Liang H, Haykal R, Kaiksow F, Mazza JJ, Yale SH. Erythrocyte Sedimentation Rate and C-reactive Protein Measurements and Their Relevance in Clinical Medicine. WMJ. 2016 Dec;115 (6):317-21.

44. Pepys MB, Gideon MH. C-reactive protein: a critical update. J Clin Invest 2003; 111:1805-11.

45. Jaye DL, Waites KB. Clinical applications of C-reactive protein in pediatrics. Pediatr Infect Dis J. 1997;16(8):735-746; quiz 746-747. doi:10.1097/00006454-199708000-00003

46. Litao, Melissa Kaori Silva, and Deepak Kamat. "Erythrocyte Sedimentation Rate and C-Reactive Protein: How Best to Use Them in Clinical Practice." Pediatric Annals Pediatr Ann 43.10 (2014): 417-20. Web.

47. Kushner, Irving, Debra Rzewnicki, and David Samols. "What Does Minor Elevation of C-Reactive Protein Signify?" The American Journal of Medicine 119.2 (2006): n. pag. Web.

48. Wenner M, Daum P, McQuillan G. The influence of age, sex, and race on the upper reference limit of serum C-reactive protein concentration. J Rheumatol 2000; 27(10):2351.

49. Vanderschueren S, Deeren D, Knockaert DC et al. Extremely elevated C-reactive protein. Eur J Intern Med 2006; 17:4303 .

50. Vanderschueren, Steven, Dries Deeren, Daniël C. Knockaert, Herman Bobbaers, Xavier Bossuyt, and Willy Peetermans. "Extremely Elevated C-reactive Protein." European Journal of Internal Medicine 17.6 (2006): 430-33. Web.

51. Anurag Markanday. Acute Phase Reactants in Infections: Evidence-Based Review and a Guide for Clinicians. Open Forum Infect Dis. 2015 Sep; 2(3): ofv098. Published online 2015 Jul 3. doi: 10.1093/ofid/ofv09852.

52. Silvestre J, Coelho L, Povoa P. Impact of fulminant hepatic failure in C-reactive protein. J Crit Care 2010; 25 : e7-12.

53. Silvestre JP, Coelho LM, Povoa PM. Impact of fulminant hepatic failure in C-reactive protein?J Crit Care. 2010;25(4): 657.e7-12. doi: 10.1016/j.jcrc.2010.02.004

54. Ohsawa M, Okayama A, Nakamura M, Onoda T, Kato K, Itai K, Yoshida Y, Ogawa A, Kawamura K, Hiramori K. CRP levels are elevated in smokers but unrelated to the number of cigarettes and are decreased by long-term smoking cessation in male smokers. Prev Med. 2005 Aug;41(2):651-6. doi: 10.1016/j.ypmed.2005.02.002. PMID: 15917065.

55. Dana E. King, Arch G. Mainous III, Thomas A. Buchanan, William S. Pearson. C-Reactive Protein and Glycemic Control in Adults with Diabetes. Diabetes Care 2003 May; 26(5): 1535-1539. https://doi.org/10.2337/diacare.26.5.1535

56. Chae CU, Lee RT, Rifai N, Ridker PM. Blood pressure and inflammation in apparently healthy men. Hypertension. 2001; 38: 399-403.

57. Cho HJ, Seeman TE, Bower JE, Kiefe CI, Irwin MR. Prospective association between C-reactive protein and fatigue in the coronary artery risk development in young adult study. Biol Psychiatry. 2009;66(9):871-878. doi:10.1016/ j.biopsych. 2009.06.008

58. Wium-Andersen MK, Ørsted DD, Nielsen SF, Nordestgaard BG. Elevated C-Reactive Protein Levels, Psychological Distress, and Depression in 73131 Individuals. JAMA Psychiatry. 2013;70(2):176-184. doi:10.1001/2013.

59. Wyczalkowska-Tomasik A, Czarkowska-Paczek B, Zielenkiewicz M, Paczek L. Inflammatory Markers Change with Age, but do not Fall Beyond Reported Normal Ranges. Arch Immunol Ther Exp (Warsz). 2016; 64(3):249-254. doi:10.1007/s00005-015-0357-7

60. Michael Harrison. Erythrocyte sedimentation rate and C-reactive protein. Aust Prescr. 2015 Jun; 38(3): 93-94. Published online 2015 Jun 1. doi: 10.18773/austprescr.2015.034 


\section{International Journal of Current Science Research and Review}

ISSN: 2581-8341

Volume 04 Issue 02 February 2021

DOI: 10.47191/ijcsrr/V4-i2-07, Impact Factor: 6.825

IJCSRR@ 2021

61. A Osei-Bimpong 1, J H Meek, S M Lewis. ESR or CRP? A comparison of their clinical utility. Hematology. 2007 Aug;12(4):353-7. doi: 10.1080/10245330701340734.

62. igal LH. Molecular biology and immunology for clinicians: the acute phase reaction, J Clin Rheumatol, 1997, vol. 3 (pg. 28-34)

63. Stephanie Sbong, Mark Feldman. Frequency and causes of C-reactive protein and erythrocyte sedimentation rate disagreements in adults. International Journal of Rheumatic Diseases. First published: 31 December 2014.

https://doi.org/10.1111/1756-185X.12537Citations: 9

64. Colombet I, Pouchot J, Kronz V et al. (2010) Agreement between erythrocyte sedimentation rate and C-reactive protein in hospital practice. Am J Med 123, 863.e7-e13

65. Felman M, Aziz B, Kang G, et al. C-reactive protein and erythrocyte sedimentation rate discordance: frequency and causes in adults. Translational Research 2013; 161:37-43.

66. Harrison M. Australian Prescriber 2015; 38:93-4.

67. Buess T, Ludwig C. Diagnostic value of C-reactive protein in comparison with erythrocyte sedimentation as routine admission diagnostic test. Schweiz Med Wochenschr. 1995 Jan 28;125 (4):120-4.

68. Ahmed MS, Jadhav AB, Hassan A, Meng QH. Acute phase reactants as novel predictors of cardiovascular disease. ISRN Inflamm. 2012 May 06; 2012:953461.

Cite this Article: Arash Eatemadi, Ali Al Madhani, Ahmed Al Maqbali, Hamid Moradzadegan (2021). Dynamics of Erythrocyte Sedimentation Rate vs. C - reactive protein: Peas in a Pod or Chalk and Cheese?. International Journal of Current Science Research and Review, 4(2), 120-126 